\title{
The Pictorial Turn
}

\section{Aleš Erjavec}

In 1993 Martin Jay published his influential book Douncast Eyes: The Denigration of Vision in Twentieth-Century French Thought. ${ }^{1}$ In this work, which offered a comprehensive survey of twentieth century French philosophy, Jay argued that much if not all of the past century's French philosophy - a visible exception being Maurice Merleau-Ponty's existential phenomenology, which was even named an "ontology of sight" - was visibly anti-ocular if not altogether iconoclastic, in this way echoing previous linguistic turns in European history, starting with Tertullian and similar Christian thinkers. In those early times, such theoretical defenders of Christianity obviously had to counter what was then the still allpervading Greek and Roman idolatry and obsession with the spectacle. To counter it they accentuated its opposite, i.e. the iconoclasm arising from the Jewish roots of Christianity and the prohibition of making graven images. A related effect was the importance ascribed to words, a combination repeated in Protestant theory and practice much later.

Hence, there exists a similarity between these ideas from the early times of European thought and twentieth century French philosophy. Although it could be argued, especially if we take into consideration these observations related to the history of European thought and culture in the last two millenia, that the denigration of vision in French theory of the previous century is not such a novelty, but only continues a theoretical practice known from the less recent past, this does not answer the question of this recent need to re-enact such an iconoclastic practice. This re-enactment is relevant especially since twentieth century French philosophy remains one of the main reference points in contemporary theoretical discussions in realms usually designated as philosophy, poststructuralism, and critical theory.

The same is even true of art, such as when Marcel Duchamp designated his works as "anti-retinal", thereby stressing their anti-ocular and anti-visual character. And this is not just a casual remark, for if one has an opportunity to visit one of the relatively infrequent exhibitions of Duchamp's cuvre, one is - or at least I was when I saw the Duchamp exhibition in Palazzo Grassi in Venice in 1993 — surprised to notice the very small number of works Duchamp actually produced in his lifetime. Not only could they all be stored in a

\footnotetext{
${ }^{1}$ Martin Jay, Downcast Eyes: The Denigration of Vision in Twentieth-Century French Thought (Berkeley: University of California Press, 1993).
} 
single hall, but their material existence appears almost insignificant compared to their theoretical import and their practical artistic and cultural impact.

It certainly isn't only twentieth century French philosophy that could be designated as anti-ocular: the same is true of Martin Heidegger, who, especially in his essay "The Age of the World Picture" from 1938, argued that the whole line of philosophy from Plato and Aristotle to Cartesian and post-Cartesian thinking is transforming the world into a "picture".

The same line of thought is pervasive also in a series of other contemporary thinkers: consider Theodor Adorno's accentuation of literature and music in contradistinction to the cinema and consumer culture, or Jean Baudrillard's critique of the world of the media, not to mention another early critique of the society of the spectacle, i.e. that articulated by Guy Debord in the sixties, but which became influential only in the late eighties.

A persuasive argument for this anti-ocular orientation of the twentieth century, and especially its second half, is offered by W.J.T. Mitchell in a book which was published at approximately the same time as numerous books on vision, seeing and related topics, such as those by Svetlana Alpers, Jonathan Crary, David Michael Levin, and Christine BuciGlucksmann, among others. In his work Piiture Theory Mitchell argues:

If we ask ourselves why a pictorial turn seems to be happening now, in what is often characterized as a "postmodern" era, the second half of the twentieth century, we encounter a paradox. On the one hand, it seems overwhelmingly obvious that the era of video and cybernetic technology, the age of electronic reproduction, has developed new forms of visual simulation and illusionism with unprecedented powers. On the other hand, the fear of the image, the anxiety that the "power of images" may finally destroy even their creators and manipulators, is as old as image-making itself. Idolatry, iconoclasm, iconophilia, and fetishism ate not uniquely "postmodern" phenomena. What is specific to our moment is exactly this paradox. The fantasy of a pictorial turn, of a culture totally dominated by images, has now become a real technological possibility on a global scale. ${ }^{2}$

It was in the sixties that the first broad and infuential theoretical assault in the twentieth century was launched upon the visual culture. I am referring to the critique offered by the Frankfurt School and aimed at American and American-style consumer culture, as exemplified by television, commercials, billboards and consumerism in general. The whole idea of the post-war neoavant-garde art - minimalism, fluxus, conceptual art, abstract expressionism, but with the exception of pop art - could be regarded as an artistic critique of the image at the expense of concept and theory. A related attack on images occured in France and was related to the events of ' 68 and theoretically developed in Debord's critique

${ }^{2}$ W.J.T. Mitchell, Picture Theory (Chicago: Chicago University Press, 1994), 15. 
of "the society of the spectacle" and the critique of the Imaginary as opposed to the Symbolic as presented in the dominant psychoanalytical theories. Even though Gilles Deleuze, Félix Guattari and the early Jean-François Lyotard attempted to counter this trend and to point to the positive aspects of the figurative and the Imaginary, their efforts never attained results comparable to those of their theoretical adversaries. In the seventies a similar critique was launched also in the other great world power of that day, i.e. in the Soviet Union, wherein Russian artists, such as Erik Bulatov, compared the American omnipresence of consumer and market ideology with a similar Soviet omnipresence of political ideology, which was also displayed publicly in the form of slogans, commercials, billboards and other visual means wherein the discursive, the textual component was subsumed to the visual effects of the ideological imagery.

One of better-known of Jean-Paul Sartre's claims was that Guernica hasn't changed anybody's political opinions, while the written word has changed many. It is only within the context of pre-modernism and modernism that this thesis holds true. Within the postindustrial and postmodern context of the contemporary epoch of multinational capital, the notion of traditional political ideology itself loses much of its import. Such an ideology has digressed on the level of the "microphysics of power", to use an apt phrase by Michel Foucault; the logic of power is increasingly complex and interrelated, power is decentered, and ideology has become, contrary to that described by Claude Lefort in the seventies as invisible, superficial: it is all on the surface and controlled by the logic of the capital. As Fredric Jameson once noted, when describing this situation, "it seems to be easier for us today to imagine the thoroughgoing deterioration of the earth and of nature, than the breakdown of late capitalism". ${ }^{3}$

It is within this capitalist system that the notion of the pictorial turn should be discussed. But even though the pictorial turn is intrinsically related to that offered by the consumer culture in the sixties, at that time it was predominantly an American cultural phenomenon, while today it is omnipresent in all First World countries. Moreover, today its radical theoretical and even political critique is absent, revealing in this indirect way a thoroughly changed political and theoretical culturescape. This is so because no viable alternative to the extant social, cultural and economic order exists, the ensuing situation being such that, as Slavoj Žižek has recently noted, today the right offers more persuasive and viable options than the left. Due to this change of polatities and the transformation of the whole system constituting such a dichotomy, the pictorial turn appears increasingly as an integral part of the broader aesthetic turn.

\footnotetext{
${ }^{3}$ Fredric Jameson, The Seeds of Time (New York: Columbia University Press, 1994), xii.
} 
But, are we today really aware of the presence of the pictorial turn? It is not only television, the clothes we wear with their logotypes that function in accordance with Baudrillard's analysis of the consumption of the symbolic value (and not the use value) of commodities, it is not only the increasing flux of history and the contemporary lack of cognitive mapping which often causes disorientation, the disappearance of the sense of history and of historical perspective (the much debated "end of history"), but also the almost complete commodification of everything existing. This "everything existing" is no longer an object of uncompromising critique but an object that allows and helps us attain gratification.

All that I have here briefly sketched is available to our consciousness and even critique only when it can be regarded as a "turn": only in the consciousness of the change, of the transformation and the difference, is this "other" of the "same" sensed and perceived. Once it becomes an everyday monotonous occurrence it is already the same, the difference is no longet sensed, the "turn" has been achieved and there is no longer any immediate turn to be diagnosed, evaluated, criticized or praised.

Let me repeat the already quoted passage from Mitchell's Picture Theory: "What is specific to our moment is exactly this paradox. The fantasy of a pictorial turn, of a culture totally dominated by images, has now become a real technological possibility on a global scale." Although Mitchell's diagnosis is not that recent, the turn it notes is still with us, that is, it still functions as a "passage" from one symbolic, imaginary and social universe to the other. It is true that even in its most complete form it can only exist as a "dominant", but it is questionable whether even this is possible on a global scale, except as an imaginary form of an object of desire which allows us to become oblivious to the past and the future.

So, to come to the point, can it be said that a pictorial turn has already been achieved? I believe it would be premature to make such a claim and I would like to offer three arguments why this is not so:

(1) First, a turn must be universal, that is to say, it must involve all segments of the social field or of the social universe. Taking as my starting point Claude Lefort's work Les formes de l'bistoire, ${ }^{4}$ I would atgue that no ideology is total. Even if it employs all the mechanisms and apparatuses that are at its disposal, sooner or later something unprecedented occurs, something that cracks the invisible discursive and symbolic membrane of what appears to be an indestructible ideology. A novelty appears, be it in the form of new ideas, art forms, nonconformist behavior, etc. In a similar vein, the pictorial turn can be the pervasive form, but it certainly isn't the only form, for otherwise we would not be at this conference here

\footnotetext{
${ }^{4}$ Claude Lefort, Les formes de l'bistoire (Paris: Gallimard, 1978).
} 
and today. It is true that the pictorial turn does not necessarily entail a complete change of cultural patterns, although it is also true, as Fredric Jameson often argued, that contermporary culture is thoroughly commodified, and that it is also a predominantly visual one. Since it is visual, it is universally acceptable, and since it can be transmitted by everdeveloping technical means, it is also the most global and at the same time the most easily global.

(2) Second, the turn is not universal in the sense that it does not encompass all segments of the globe. While it is true that a pictorial turn is being disseminated by global capitalism, by television and in innumerable other ways, it is also true that in many parts of the globe much of Asia or in Latin America, to note but two - art, theory and discourse in general, still carry potentials that are far from being obsolete. In these places, as in many others, the pictorial turn is only in the making, although it is true that it is developing at a rate and in forms that differ from those witnessed in the First World. Not only does language set the borders to my mind, but also my human experience and familiarity do. In places like Btazil, Paraguay, China, South Korea or India, Slovakia and so on, the pictorial turn is either not equally present as in the most developed countries and cultures of the world, or functions differently, that is to say, it is formed according to its local and marginalist specifics.

(3) Today, perhaps because of globalization, everybody shares the same sentiment of being on the margin: people in Slovenia think that the center is, say, Paris, London or New York, while our colleagues in Paris think it is New York, with those from San Francisco or London being certain that it is actually Paris, Vienna or Berlin. I don't have to mention Australians or South Africans. In other words, everybody feels on the margin, while the center functions as a nonexistent object of desire. Here lies the third reason why the pictorial turn is not as prevalent as we perhaps assume. This reason has to do with marginality: different countries, cultures and parts of the world no longer communicate with each other in a singular fashion, and events that occur in various parts of the world no longer allow us to view them in a single and uni-centeted way. If Goethe is considered to have been the last intellectual of whom it could be claimed that he possessed all the scientific knowledge of his time, today nobody can claim that he or she - whether we are referring to individuals, groups, think tanks or television networks - possesses the "knowledge" of what is going on in their own, let alone some other part of the world. Global existence has become so complex that "cognitive mapping" is setiously hindered, and it is also for this reason that the pictorial turn may appear to be one of the rare visible phenomena holding this world together. 
Let me end with two notes, one on art and another on aesthetics:

We know that much of contemporary art is no longer visual but rather falls under the rubric of art of the kind that Marcel Duchamp started at the beginning of the twentieth century. Could it be claimed, perhaps, that in reality, that is, unconsciously, the conceptual and neoconceptual art is part and parcel of the same anti-ocular trend that Jay detected in twentieth century French thought and that Mitchell explained to be a reaction to the pervasiveness of the pictorial turn? Again, I can here but note this issue and not dwell upon it, although it would be interesting to explore the possibilities offered by such a perspective for they would carry consequences also for the institutional theory of art, which would then be simply recognized as a descriptive theory of art.

Secondly, and let me quote again from Mitchell's 1994 book: "If a pictorial turn is indeed occurring in the human sciences, art history could well find its theoretical marginality transformed into a position of intellectual centrality, in the form of a challenge to offer an account of its principal theoretical object - visual representation."

Since these words have been written, this has not happened, that is, art history has not attained the central position Mitchell saw as a viable option for its future development. Instead, it appears that philosophy of art and philosophy of culture in their various forms are hegemonizing this territory. Again, I can only offer a brief argument for such a course of events: it may be that philosophy (as that essential part of aesthetics understood as the philosophy of art and culture) has remained that undifferentiated realm of knowledge which is most of all exemplified by its incessant self-critique, as begun by both Descartes and Kant. In this way philosophy has avoided the disciplinary differentiation which occurred mostly in the nineteenth century and which today, in a period of dedifferentiation (as diagnosed by Susan Sontag in the sixties and then further elaborated by Scott Lash a decade ago) is no longer viable. It remains to be seen whether philosophies of art and culture can actually carry out the agenda of analyzing the on-going ocularcentrism and the contemporary visual representation as one of its main topics. By doing this they can offer an undetstanding of the visual social and historical phenomena which would equal those of the previous, i.e. modernist epoch, wherein the central role appertained to literature and written discourse. In other words, philosophies of art and culture could offer some kind of a cognitive mapping, the actual realization of which, although very much needed, is still not yet within our grasp."

${ }^{5}$ Mitchell, Picture Theory, 15.

"This paper is based on my essay "Dass fällt ins Auge ...", Gianni Vattimo \& Wolfgang Welsch, eds., Medien - Welten - Wirklichkeiten (München: Wilhelm Fink, 1998), pp. 39-57. In English available as: "That Meets the Eye...", AE, winter/hiver 1998, no. 2 (http://tornade.ere.umontreal.ca/ quer don/AE/vol_2/ erjavec.html) 